\title{
Bio-Polyurethane Resins Derived from Liquid Fractions of Lignin for the Modification of Ramie Fibers
}

Manggar Arum Aristri ${ }^{1}$, Muhammad Adly Rahandi Lubis, ${ }^{1, *}$, Raden Permana Budi Laksana ${ }^{1}$, Faizatul Falah $^{1}$, Widya Fatriasari ${ }^{1}$, Maya Ismayati ${ }^{1}$, Asri Peni Wulandari ${ }^{2}$, Nurindah ${ }^{3}$, Muhammad Rasyidur Ridho ${ }^{1}$

${ }^{1}$ Research Center for Biomaterials, Indonesian Institute of Sciences (LIPI). Jl. Raya Bogor Km. 46 Cibinong, Bogor, 16911, Jawa Barat, Indonesia

${ }^{2}$ Departement of Biology, Faculty of Mathematics and Natural Sciences, Universitas Padjajaran. Jatinangor, West Java, 45363, Indonesia

${ }^{3}$ Indonesian Sweetener and Fiber Crops Research Institute, Ministry of Agriculture. Malang, East Java, 65152, Indonesia

* Corresponding author. E-mail address: marl@biomaterial.lipi.go.id

\section{ARTICLE HISTORY:}

Received: 13 February 2021

Peer review completed: 6 March 2021

Received in revised form: 8 March 2021

Accepted: 12 March 2021

\section{KEYWORDS}

Bio-polyurethane resins Impregnation Lignin fractions

Ramie fibers

Thermal stability
(C) 2021 The Author(s). Published by Department of Forestry, Faculty of Agriculture, University of Lampung in collaboration with Indonesia Network for Agroforestry Education (INAFE).

This is an open access article under the CC BY-NC license:

https://creativecommons.org/licenses/bync/4.0/.

\begin{abstract}
In this study, technical lignin from black liquor was used as a pre-polymer for the preparation of bio-polyurethane (Bio-PU) resins. Briefly, the isolated lignin was fractionated using ethyl acetate (EtAc) and methanol $(\mathrm{MeOH})$. The liquid fractions of lignin, such as lignin-EtAc (L-EtAc) and lignin-methanol $(\mathrm{L}-\mathrm{MeOH})$, were mixed with $10 \%$ of polymeric isocyanate (based on the weight of liquid fractions) to obtain Bio-PU resins. The isolated lignin, fractionated lignin, and lignin-derived Bio-PU resins were characterized using several techniques. The obtained Bio-PU resins were then used to modify ramie fibers using vacuum impregnation method. Fourier Transform Infrared (FTIR) spectroscopy, Differential Scanning Calorimetry (DSC), and Thermogravimetric Analysis (TGA) revealed that the isolated lignin had quite similar characteristics to the lignin standard. Fractionation of lignin with EtAc and $\mathrm{MeOH}$ altered its characteristics. FTIR, DSC, and TGA showed that solid fractions of lignin had similar characteristics to lignin standard and isolated lignin, while the liquid fractions had characteristics from lignin and the solvents. The absorption band of isocyanate $(-\mathrm{N}=\mathrm{C}=\mathrm{O})$ groups was shifted to $2285 \mathrm{~cm}^{-1}$ from $2240 \mathrm{~cm}^{-1}$ owing to the reaction with the $-\mathrm{OH}$ groups in lignin, forming urethane $(\mathrm{R}-\mathrm{NH}-\mathrm{C}=\mathrm{O}-\mathrm{R})$ groups at $1605 \mathrm{~cm}^{-1}$ in Bio-PU resins. Thermal properties of Bio-PU resins derived from L-EtAc exhibited greater endothermic reaction compared to Bio-PU-L-MeOH. As a result, the free $-\mathrm{N}=\mathrm{C}=\mathrm{O}$ groups in Bio-PU resins have reacted with $-\mathrm{OH}$ groups on the surface of ramie fibers and improved its thermal properties. Modification of ramie fibers with Bio-PU resins improved the fibers' thermal stability by $15 \%$ using Bio-PU-LEtAc for 60 min of impregnation.
\end{abstract}

\section{Introduction}

Lignin is the second most abundant biopolymer after cellulose obtained from agroforestry biomass. It is found in all lignocellulosic plants and is derived after deposition of the carbohydrates (Boerjan et al. 2003). Lignin is regarded as a key raw material to achieve a sustainable forest product bioeconomy, particularly for the pulp and paper industry (Wenger et al. 2020). Lignin is a renewable, amorphous, and aromatic biopolymer, isolated from black liquor which is a by- 
product of the pulp and paper industry (Krutov et al. 2014). The pulp and paper industry worldwide produces an estimated 40-50 million tons of lignin annually (FAO 2019). The chemical composition of black liquor depends on the source of the raw fiber and therefore determines its physical properties. The high solids content and availability of black liquor as the main by-product of the pulp and paper industry make great use of black liquor as a strategic and promising raw material for lignin (Antov et al. 2021). This isolated lignin from black liquor is referred to technical lignin (El Mansouri and Salvadó 2007). Lignin provides greater prospects for higher added value applications in renewable products. Lignin polymers contain several important functional groups, including phenolic hydroxyl, aliphatic hydroxyl, and carboxylic acid groups (Antov et al. 2020a; Solihat et al. 2021). The reactivity of different lignins depends on their chemical structure. Therefore different lignin samples contain different types and numbers of these functional groups, which can be used to manufacture industrial biomaterials and biocomposites (Antov et al. 2020b; Falah et al. 2020).

Technical lignin can be converted to the industrial one by fractionation. Technical lignin has broad molecular weight distribution, between $1000 \mathrm{~g} / \mathrm{mole}$ and 100,000 g/mole, makes it difficult to commercially utilize lignin (Toledano et al. 2010). Fractionation of lignin has two potential benefits: chemical structure versus bulk property relationship can be obtained, and the fractions themselves can have properties useful for various applications (Velez and Thies 2013). There are three available fractionation methods of lignin. The first one is differential precipitation, which extracts lignin from black liquor by decreasing the $\mathrm{pH}$ gradually, using a strong mineral acid (García et al. 2009). This method produces a high yield of lignin, but due to the formation of colloids during precipitation, it results in relatively low purity of the isolated lignin. The second method uses selective solvents for the lignin extraction, with the help of enzymes, catalysts, and ionic liquids to obtain low molecular weight lignin (Toledano et al. 2010). This method allows to produce high added value products from the isolated lignin but with very high production costs. The last method utilizes membrane technology to obtain lignin fractions with specific molecular weight distributions without using chemicals (Jönsson et al. 2008). The fractions of lignin are more suitable to be used as building blocks for bio-based polymers such as bio-based polyurethane (PU) resins (Griffini et al. 2015; Wang et al. 2019). Cross-linked PU resins polymer from the liquid fractions of lignin has good thermal and thermomechanical properties and a good shape memory effect. PU resins polymer is one of the most useful and multi-purpose polymers with formulation covering a wide range of products and applications. So far, many types of polyols and diisocyanates have been explored to prepare the PU resins. Compared with petroleum polyol-based materials, lignin-based polyols are more environmentally friendly, biodegradable, cost less, and exhibit potential application for developing economic and sustainable PU resins (Alinejad et al. 2019).

Ramie (Boehmeria nivea (L.) Gaudich) fibers are bast fibers, which are extensively available in nature, native in China, and widespread in Asia (Angelini et al. 2000). Ramie fibers are known as one of the fully biodegradable natural fibers, characterized by a high strength $(61-128 \mathrm{GPa})$, small diameter $(10-60 \mu \mathrm{m})$, low specific density $\left(1.5 \mathrm{~g} / \mathrm{cm}^{3}\right)$, antibacterial properties, higher absorbency, air permeability, and lower wrinkle characteristics, with higher cellulose content of approximately 65-75\% compared to other bast fibers (Angelini et al. 2015; Du et al. 2015; Li et al. 2015; Yuan et al. 2016). Ramie fibers have been used as raw material for composites and textiles to replace synthetic fiber-oriented composites due to their outstanding biodegradability, renewability, decomposability, stiffness, higher length-to-weight ratio, and low cost (Angelini et 
al. 2015; Djafar et al. 2020). However, the negative characteristics of ramie fibers are flammability and thermal instability (Dorez et al. 2013).

This research is aimed to prepare and characterize bio-polyurethane (Bio-PU) resins from liquid fractions of lignin and use the Bio-PU resins for modification of ramie fibers. In this study, the black liquor obtained from the pulp and paper industry was used as starting material for isolated lignin. The isolated lignin was fractionated prior to the preparation of Bio-PU resins. Ramie fibers were modified using the obtained Bio-PU resins. Several techniques were employed to characterize the isolated lignin, fractionated lignin, Bio-PU resins, and ramie fibers.

\section{Materials and Methods}

\subsection{Materials}

Black liquor of Acacia mangium kraft pulping with 70\% solids content was obtained from PT. Tanjung Enim Lestari Pulp and Paper (PT. TELPP, South Sumatera, Indonesia. For comparison, commercial lignin from Sigma Aldrich was also used to a similar design condition. $\mathrm{HCl}(37 \% \mathrm{w} / \mathrm{v})$ was used for lignin isolation process. Organic solvents, namely ethyl acetate (EtAc) and methanol $(\mathrm{MeOH})$, were used for lignin fractionation. Standardized kraft lignin from Sigma Aldrich (CAS No. 8068-05-1) was used as a standard. Polymeric 4,4-methane diphenyl diisocyanate (pMDI, 31\% NCO content) was purchased from Anugrah Raya Kencana Company (ARK, Banten, Indonesia) for the preparation of bio-polyurethane pre-polymer. Degummed ramie fibers were obtained from a local farmer at CV. RABERSA (Wonosobo, Central Java, Indonesia).

\subsection{Methods}

\subsubsection{Isolation and fractionation of lignin}

Lignin was isolated by single step precipitation. Approximately $1 \mathrm{M}$ of $\mathrm{HCl}$ was added to $800 \mathrm{~g}$ of the black liquor, which has a $\mathrm{pH}$ of about 12 , up to the solution reached $\mathrm{pH}$ of 2 . Lignin suspensions in the acid solution obtained by the previous method were kept for $24 \mathrm{~h}$ to complete the precipitation process. Afterward, their solution was separated from the lignin precipitates by pipette, washed three times with distilled water, and then put in the freezer for $24 \mathrm{~h}$. After that, the lignin precipitates were separated from their solution by vacuum filtration and Whatman filter paper no 4 , then dried in the oven at $45^{\circ} \mathrm{C}$ or $24 \mathrm{~h}$. The yield and moisture content of lignin were characterized according to the published work (Hermiati et al. 2017).

Liquid fractions of lignin were obtained by fractionation method using two different solvents, i.e., ethyl acetate and methanol. Lignin was mixed with ethyl acetate (EtAc) with an EtAc:Lignin ratio of 15:1 in a beaker. The fractionation process was carried out for $24 \mathrm{~h}$ at room temperature with a stirring speed of $200 \mathrm{rpm}$. After the fractionation process was complete, the insoluble lignin solid EtAc (solid residue) was separated with EtAc soluble lignin (liquid fraction) by vacuum filtration and Whatman filter paper no. 4. Similar methods were also carried out for lignin fractionation with methanol $(\mathrm{L}-\mathrm{MeOH})$ solvents. Those liquid fractions of lignin were used as bio-polyurethane resins.

\subsubsection{Preparation of bio-polyurethane resins}

Two types of bio-polyurethane (Bio-PU) resins were produced using the liquid fractions of lignin, namely L-EtAc and L-MeOH. pMDI was diluted with acetone until reaching 50\% of 
concentration and then was used as a component for bio-polyurethane pre-polymer. Approximately $25 \mathrm{~mL}$ of each liquid fraction of lignin was mixed with $10 \%$ of diluted pMDI based on the weight of the liquid fractions in $100 \mathrm{~mL}$ of beaker glass under $300 \mathrm{rpm}$ of stirring speed. The reaction was carried out under rapid stirring of $500 \mathrm{rpm}$ at $25^{\circ} \mathrm{C} \pm 2^{\circ} \mathrm{C}$ for $1 \mathrm{~h}$, as shown in Fig. 1.
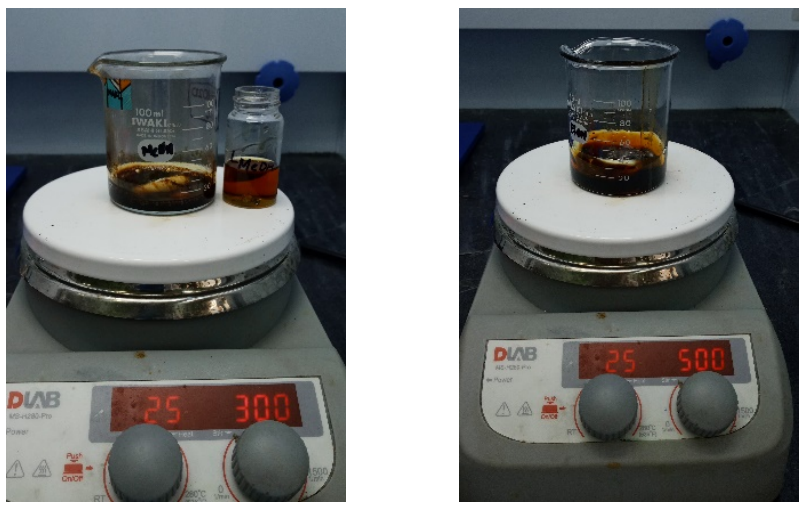

Fig. 1. Preparation of Bio-PU resins derived from liquid fractions of lignin.

\subsubsection{Characterization of lignin and bio-polyurethane resins}

Functional groups of isolated lignin, fractionated lignin, and Bio-PU resins were investigated using Fourier Transform Infra-Red (FTIR) spectroscopy (SpectrumTwo, Perkin Elmer Inc., USA) by the Universal Attenuated Total Reflectance (UATR) method. Lignin and its fractions samples were scanned from $4000-400 \mathrm{~cm}^{-1}$ at $23^{\circ} \mathrm{C} \pm 2{ }^{\circ} \mathrm{C}$ with an accumulative of 16 scans. Each spectrum was normalized using min-max normalization in Spectrum software (Ver. 10.5.3, Perkin Elmer Inc., USA).

Thermal behavior of isolated lignin, fractionated lignin, and Bio-PU resins were analyzed using Differential Scanning Calorimetry (DSC 4000, Perkin Elmer Inc., USA). Around 5 mg \pm 0.5 $\mathrm{mg}$ of each sample was put in a standard aluminum pan and heated from $0^{\circ} \mathrm{C}$ to $300^{\circ} \mathrm{C}$ at a heating rate of $10^{\circ} \mathrm{C} / \mathrm{min}$ under nitrogen flow of $20 \mathrm{~mL} / \mathrm{min}$. The endothermic peak temperature $\left(T_{p}\right)$ of each sample was detected using Pyris software (Ver. 13.3.1, Perkin Elmer Inc., USA).

Thermal stability of isolated lignin, fractionated lignin, and Bio-PU resins were investigated using Thermogravimetric Analyzer (TGA 8000, Perkin Elmer Inc., USA). Each sample was heated from $25^{\circ} \mathrm{C}$ to $750^{\circ} \mathrm{C}$ at a heating rate of $10^{\circ} \mathrm{C} / \mathrm{min}$. Nitrogen gas was purged with a flow of 20 $\mathrm{mL} / \mathrm{min}$ during the analysis. Weight loss and its derivative thermogravimetric (DTG) were calculated using Pyris software (Ver. 11.1.1, Perkin Elmer Inc., USA).

\subsubsection{Impregnation of Ramie Fibers With Bio-Polyurethane Resins}

Degummed ramie fibers were impregnated with Bio-PU-L-EtAc and Bio-PU-L-MeOH resins. Impregnation was performed in $1 \mathrm{~L}$ vacuum chambers with a 2 -stage vacuum pump (VC0918SS, VacuumChambers.ue., USA) as depicted in Fig. 2. The initial weight of ramie fibers was recorded prior to vacuum impregnation. Approximately $5 \mathrm{~g}$ of ramie fibers were immersed in $50 \mathrm{~mL}$ of Bio-PU resins and vacuum impregnated at $25^{\circ} \mathrm{C} \pm 2{ }^{\circ} \mathrm{C}$ under $50 \mathrm{kPa}$ for 30 and $60 \mathrm{~min}$. Then, the impregnated fibers were dried in an oven at $60^{\circ} \mathrm{C}$ for $24 \mathrm{~h}$. The dried ramie fibers were weighed to determine the weight gain after impregnation. The weight gain (\%) was calculated by 
dividing the mass of ramie fibers after impregnation with the initial mass of ramie fibers. The impregnated ramie fibers were then stored in zip-lock plastic bags for further examination.

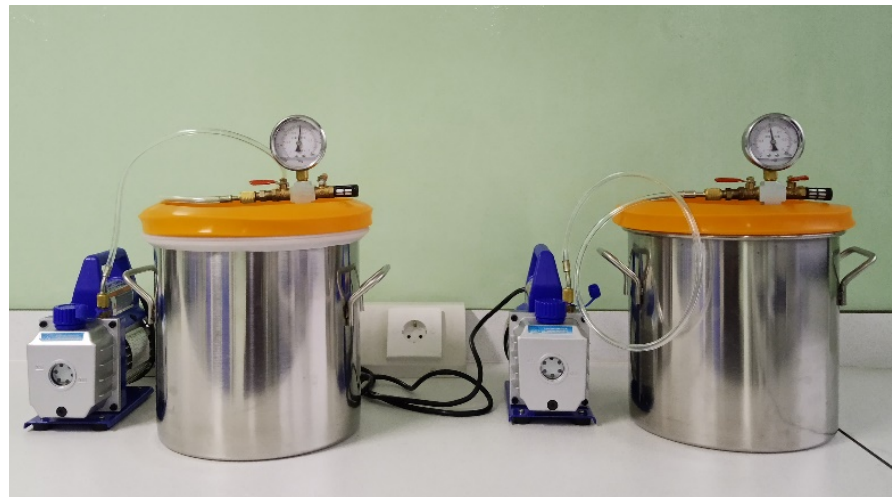

Fig. 2. A set of vacuum chamber for impregnation of ramie fibers with Bio-PU resins.

\subsubsection{Evaluation of ramie fibers properties}

Functional groups of ramie fibers before and after impregnation with Bio-PU resins were investigated using Fourier Transform Infra-Red (FTIR) spectroscopy (SpectrumTwo, Perkin Elmer Inc., USA) with Universal Attenuated Total Reflectance (UATR) method. The fibers were scanned from $4000-400 \mathrm{~cm}^{-1}$ at $23^{\circ} \mathrm{C} \pm 2^{\circ} \mathrm{C}$ with an accumulative of 16 scans. Each spectrum was normalized using min-max normalization in Spectrum software (Ver. 10.5.3, Perkin Elmer Inc., USA).

Thermal behavior of ramie fibers before and after impregnation with Bio-PU resins were analyzed using Differential Scanning Calorimetry (DSC 4000, Perkin Elmer Inc., USA). Around $5 \mathrm{mg} \pm 0.5 \mathrm{mg}$ of each sample was put in a standard aluminum pan and heated from $0^{\circ} \mathrm{C}$ to $300^{\circ} \mathrm{C}$ at a heating rate of $10^{\circ} \mathrm{C} / \mathrm{min}$ under nitrogen flow of $20 \mathrm{~mL} / \mathrm{min}$. The endothermic and exothermic peak temperature $\left(T_{p}\right)$ of each sample was detected using Pyris software (Ver. 13.3.1, Perkin Elmer Inc., USA).

Thermal stability of ramie fibers before and after impregnation with Bio-PU resins was investigated using Thermogravimetric Analyzer (TGA 8000, Perkin Elmer Inc., USA). Each sample was heated from $25^{\circ} \mathrm{C}$ to $750^{\circ} \mathrm{C}$ at a heating rate of $10^{\circ} \mathrm{C} / \mathrm{min}$. Nitrogen gas was purged with a flow of $20 \mathrm{~mL} / \mathrm{min}$ during the analysis. Weight loss and its derivative thermogravimetric (DTG) were calculated using Pyris software (Ver. 11.1.1, Perkin Elmer Inc., USA).

\section{Results and Discussion}

\subsection{Characteristics of Lignin}

FTIR spectroscopy of lignin standard and isolated lignin are shown in Fig. 3. Lignin standard and isolated lignin exhibited a broad absorption band at $3365 \mathrm{~cm}^{-1}$ that represented the $\mathrm{O}-\mathrm{H}$ stretching vibrations in phenolic and aliphatic $\mathrm{O}-\mathrm{H}$ groups, $2930-2825 \mathrm{~cm}^{-1}$ assigned to $\mathrm{C}-\mathrm{H}$ stretching of $\mathrm{CH}_{3}$ and $\mathrm{CH}_{2}, 1705 \mathrm{~cm}^{-1}$ attributed to $\mathrm{C}=\mathrm{O}$ stretching of unconjugated ketone, carbonyl, and ester groups, and $1595-1510 \mathrm{~cm}^{-1}$ represented to $\mathrm{C}-\mathrm{C}$ stretching of aromatic ring (Jung et al. 2015; Tejado et al. 2007). The main difference between lignin standard and isolated lignin was at wavenumber of $1080 \mathrm{~cm}^{-1}$, which was only detected in the lignin standard. This band was attributed to $\mathrm{C}-\mathrm{O}$ groups of primary alcohol, such as $-\mathrm{CH}_{2} \mathrm{OH}$, which was probably decomposed during acid precipitation of isolated lignin from black liquor. This study showed that 
lignin isolated from black liquor was similar to the lignin standard in terms of functional groups. The average yield of isolated lignin was around $28.8 \%$, showing that approximately $28.8 \mathrm{~g}$ of lignin can be obtained from $100 \mathrm{~g}$ of black liquor. The average moisture content of lignin was around $5.9 \%$, which is two times higher than that of the lignin standard. These results are in agreement with previously published works (Jung et al. 2015; Tejado et al. 2007).

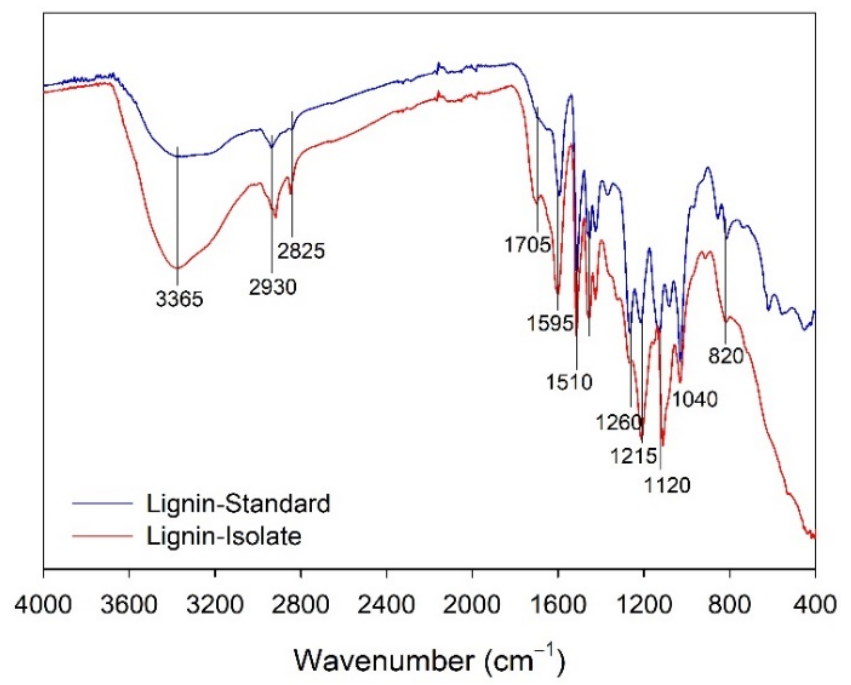

Fig. 3. Typical FTIR spectra of lignin.

Fractionation of lignin with EtAc resulted in several new functional groups (Fig. 4a). EtAc had typical functional groups at bands $3365 \mathrm{~cm}^{-1}$ with a low intensity that representing $\mathrm{O}-\mathrm{H}$ stretching, low absorption band for C-H stretching was exhibited in the area below $3000 \mathrm{~cm}^{-1}$. Sharp absorption band for $\mathrm{C}=\mathrm{O}$ stretching is shown at $1740 \mathrm{~cm}^{-1}$ and $1375 \mathrm{~cm}^{-1}$ representing $\mathrm{C}-\mathrm{H}$ bending $\left(\mathrm{CH}_{3}\right)$, while the absorption band for $\mathrm{CO}$ ethanoate appears at $1230 \mathrm{~cm}^{-1}$. A strong absorption band for $\mathrm{CO}-\mathrm{O}-\mathrm{CO}$ stretching is shown at $1040 \mathrm{~cm}^{-1}$. FTIR spectra further reveals that solid fraction of lignin after fractionation with ethyl acetate (L-EtAc) had similar functional groups with lignin standard and EtAc. This indicated that the fractionation process had been successfully carried out. It is identified by the presence of functional groups whose intensity is higher than standard lignin and solvents (EtAc) used at bands 3365, 2930, and $2825 \mathrm{~cm}^{-1}$. Besides that, there are also absorption bands at $1705 \mathrm{~cm}^{-1}, 1595 \mathrm{~cm}^{-1}, 1510 \mathrm{~cm}^{-1}, 1230 \mathrm{~cm}^{-1}$, and 1040 $\mathrm{cm}^{-1}$. While the liquid fraction (L-EtAc-liquid) had absorption bands that identify the functional groups of lignin and EtAc. Some of the absorption bands have shifted in wavenumber, e.g., 3650 $\mathrm{cm}^{-1}\left(\mathrm{O}-\mathrm{H}\right.$ stretching) and $2985 \mathrm{~cm}^{-1}$. There are more absorption bands around $3000-2800 \mathrm{~cm}^{-1}$, showing that many methyl and methylene groups are fragmented during the fractionation process. A sharp absorption band at $1740 \mathrm{~cm}^{-1}$ representing $\mathrm{C}=\mathrm{O}$ stretching, $1375 \mathrm{~cm}^{-1}$ to $\mathrm{C}-\mathrm{H}$ bending, $1230 \mathrm{~cm}^{-1}$ to $\mathrm{C}=\mathrm{O}$ stretching, and $1040 \mathrm{~cm}^{-1}$ to $\mathrm{CO}-\mathrm{O}-\mathrm{CO}$ stretching (anhydride), but in this spectra, there are several absorption bands of lignin missing because it is closed by liquid, for example in the $1595 \mathrm{~cm}^{-1}$ and $1510 \mathrm{~cm}^{-1}$ that representing $\mathrm{C}-\mathrm{C}$ stretching vibration. These results were in agreement with the published works (Chauhan et al. 2014; Griffini et al. 2015). 

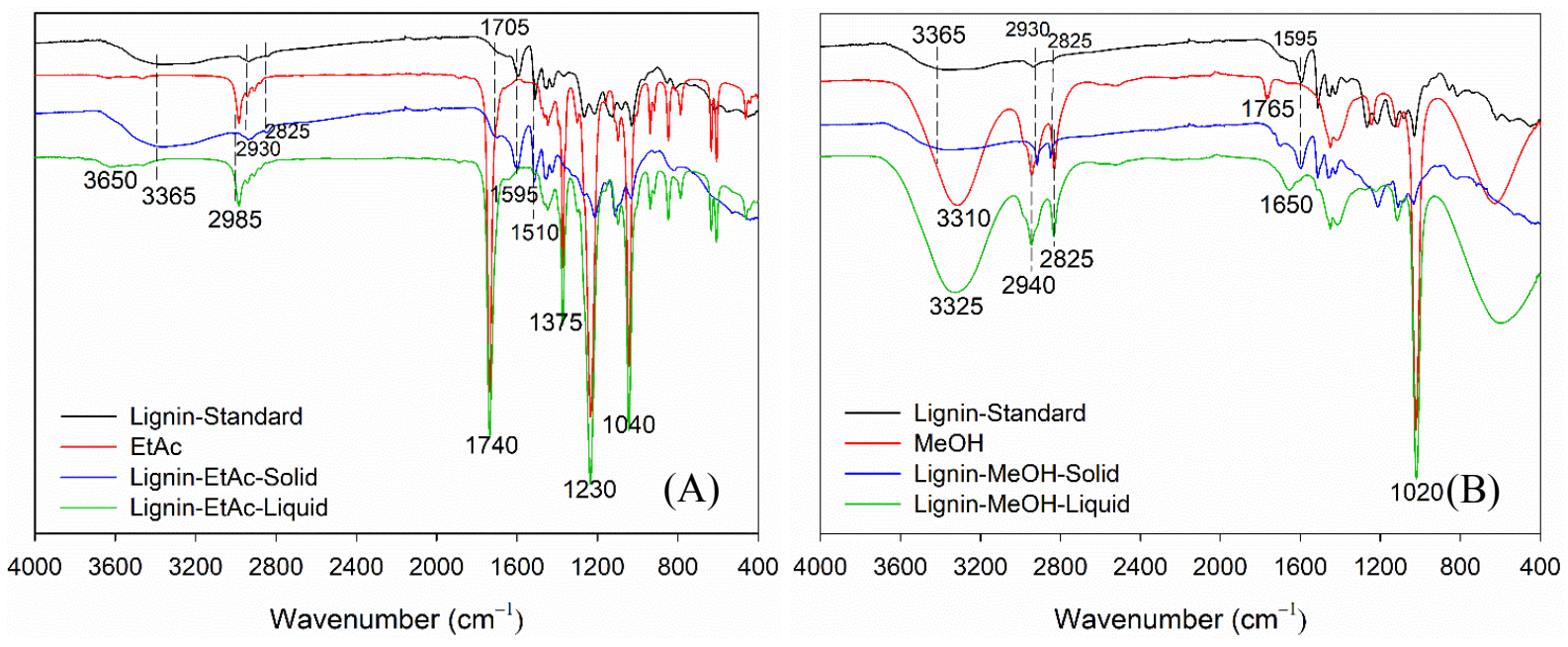

Fig. 4. Comparison of FTIR spectra of isolated and fractionated lignin: (a) fractionated with ethyl acetate (EtAc) and (b) fractionated with methanol $(\mathrm{MeOH})$.

Fig. 4b presents FTIR spectra and absorption band assignments of fractionated lignin with methanol $(\mathrm{MeOH})$. In general, $\mathrm{MeOH}$ has a medium intensity absorption band at $3310 \mathrm{~cm}^{-1}$ assigned to the $\mathrm{O}-\mathrm{H}$ stretching (alcohol), 2940 and $2825 \mathrm{~cm}^{-1}$ are attributed to the $\mathrm{C}-\mathrm{H}$ stretching, also in the fingerprint area, it has a sharp absorption band at $1020 \mathrm{~cm}^{-1}$ that represents $\mathrm{C}-\mathrm{O}$ stretching. Furthermore, there is a small absorption peak at $1765 \mathrm{~cm}^{-1}$ that represents $\mathrm{C}=\mathrm{O}$ stretching of pure $\mathrm{MeOH}$. However, the peak is no longer visible in the spectra $\mathrm{L}-\mathrm{MeOH}$-solid or L-MeOH-liquid. The fractionation process lignin with ethanol is seen in the spectra L-MeOHsolid and L-MeOH-liquid that is identified by the presence of functional groups around at 3550$3200 \mathrm{~cm}^{-1}, 3000-2840 \mathrm{~cm}^{-1}, 2830-2695 \mathrm{~cm}^{-1}$, and $1650-1566 \mathrm{~cm}^{-1}$. In these spectra, there are absorption bands between $3000-2695 \mathrm{~cm}^{-1}$ are attributed to the $\mathrm{C}-\mathrm{H}$ stretching vibrations of the methyl and methylene groups. It is identified that many methyl groups are fragmented than before (lignin without fractionation process), but there are absorption bands in the fingerprint area that are not visible in L-MeOH-solid and appear at the L-MeOH-liquid, e.g., on the absorption band at $1020 \mathrm{~cm}^{-1}$. These results were in agreement with the published works (Chauhan et al. 2014; Griffini et al. 2015).
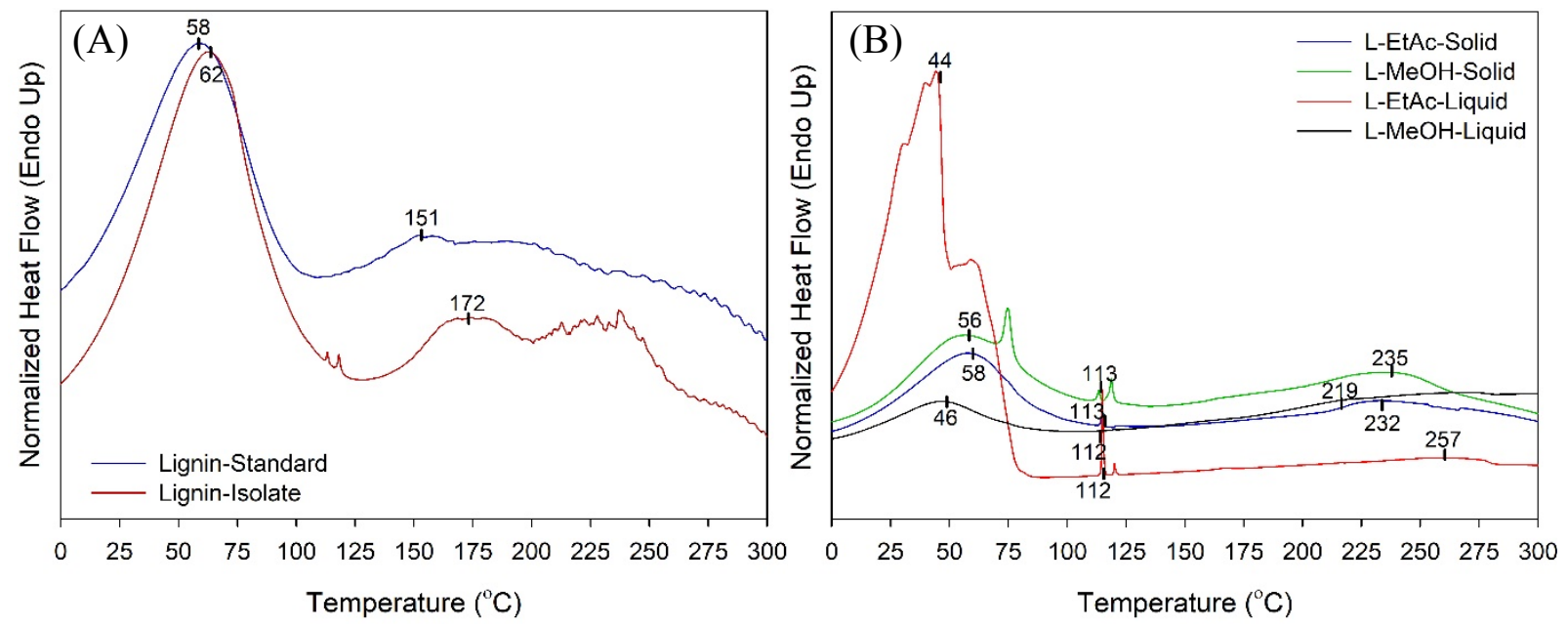

Fig. 5. DSC thermograms of lignin: (a) before fractionation and (b) after fractionation. 
The thermal behavior of lignin was investigated using DSC analysis. In general, lignin had two endothermic reactions detected in DSC thermograms (Fig. 5a). The first endothermic peak $\left(T_{p l}\right)$ occurred at around $58^{\circ} \mathrm{C}$ for lignin standard and $62^{\circ} \mathrm{C}$ for isolated lignin. During the first endothermic reaction, lignin absorbed heat from the environment to evaporate moisture. The isolated lignin had a bit higher $T_{p 1}$ due to its moisture content that was greater than the lignin standard. The second endothermic reaction was detected at $T_{p 2}$ of $151^{\circ} \mathrm{C}$ for lignin standard and $172^{\circ} \mathrm{C}$ for isolated lignin. At this temperature, lignin has been plasticized, which deformed the lignin and reduced its rigidity. This phenomenon is also known for glass transition $\left(T_{g}\right)$, where lignin generally has greater $T_{g}$ than other synthetic polymers at around $100^{\circ} \mathrm{C}$ to $180^{\circ} \mathrm{C}$ (Buranov et al. 2010). The high $T_{g}$ of lignin is because of hydrogen bonds between $-\mathrm{OH}$ of phenolic groups of lignin. Several studies reported that commercial kraft lignin has $T_{g}$ of around $93^{\circ} \mathrm{C}$ to $120^{\circ} \mathrm{C}$, softwood's lignin has an average $T_{g}$ of $158^{\circ} \mathrm{C}$, and hardwood's lignin has an average $T_{g}$ of $161^{\circ} \mathrm{C}$ (Cui et al. 2013; Jung et al. 2015). The degradation of lignin started from a temperature of $200^{\circ} \mathrm{C}$.

By contrast, fractionated lignin showed different thermal behaviors with the lignin standard and isolated lignin (Fig. 5b). The effect of solvent on lignin fractions occurred from the beginning of the endothermic reaction, where EtAc and $\mathrm{MeOH}$ volatilized at low temperature of $44^{\circ} \mathrm{C}$ to $46^{\circ} \mathrm{C}$. As the results, the $T_{p 2}$ of lignin fractions, which corresponded to $T_{g}$, was lower compared to the lignin standard and isolated lignin. $T_{p 2}$ was detected at the temperature of around $112^{\circ} \mathrm{C}$ to $113^{\circ} \mathrm{C}$. Lower $T_{g}$ of lignin fractions was obviously due to depolymerization of lignin structure. Fractionation broken down lignin macromolecules into smaller molecules Degradation of lignin fractions was detected around $219^{\circ} \mathrm{C}$ to $257^{\circ} \mathrm{C}$. These results were in agreement with the published works (Chauhan et al. 2014; Griffini et al. 2015).
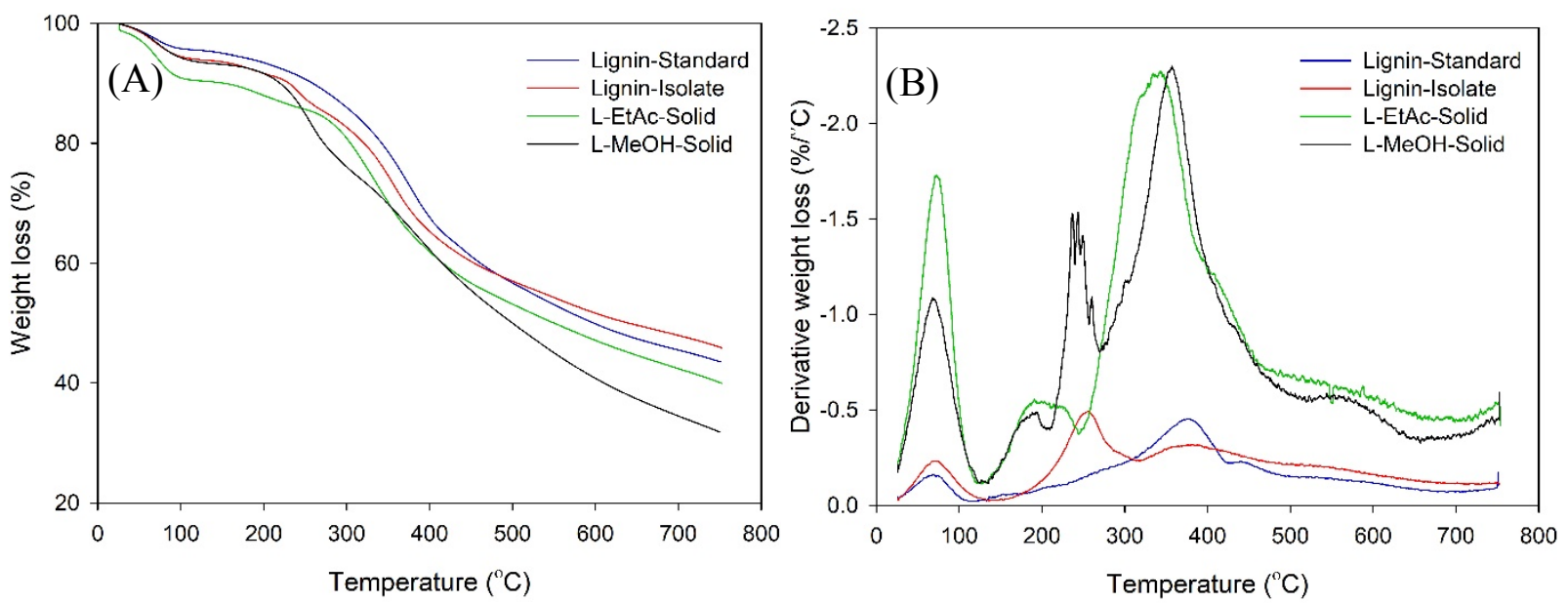

Fig. 6. Thermal stability of lignin: (a) TGA, (b) DTG.

The thermal stability of lignin was monitored by means of TGA-DTG (Fig. 6). TGA-DTG thermograms showed that three thermal degradations were detected during the analysis. The first degradation occurred at $65^{\circ} \mathrm{C}$ for lignin standard and at $70^{\circ} \mathrm{C}$ for isolated lignin owing to the evaporation of moisture in lignin. This resulted in around 5-7\% of weight loss from the lignin sample. This result was supported by a DSC analysis, which showed an endothermic reaction, occurred at around $58^{\circ} \mathrm{C}$ to $62^{\circ} \mathrm{C}$ (Fig. 6). The second degradation was detected at a temperature of $120^{\circ} \mathrm{C}$ to $480^{\circ} \mathrm{C}$, which was assigned to the lignin-carbohydrates' degradation. Initial degradation occurred at $120^{\circ} \mathrm{C}$ to $260^{\circ} \mathrm{C}$ mostly due to decomposition of carbohydrates, and then followed by degradation of lignin starting from $200^{\circ} \mathrm{C}$ to $480^{\circ} \mathrm{C}$ (Mimini et al. 2019). At this stage, 
around $32-35 \%$ of the weight of the lignin sample was lost due to thermal degradation. The last degradation was observed above $500^{\circ} \mathrm{C}$, attributed to the decomposition of the aromatic ring structure of lignin. The lignin sample was further heated to $750^{\circ} \mathrm{C}$, leaving residue of around $43 \%$ to $46 \%$ from the initial weight. This indicates that non-volatile compounds in lignin are converted to condensed aromatic structure and become residue at $750^{\circ} \mathrm{C}$ (Tejado et al. 2007).

\subsection{Properties of Bio-polyurethane Resins}

Functional groups of Bio-PU resins and their raw materials are displayed in Fig. 7a. As mentioned in the previous section, the L-EtAc-liquid fraction had an absorption band at $2985 \mathrm{~cm}^{-1}$ that corresponded to $\mathrm{C}-\mathrm{H}$ stretching, while pMDI had the sharp peak at $2240 \mathrm{~cm}^{-1}$ associated with isocyanate groups $(-\mathrm{N}=\mathrm{C}=\mathrm{O})$ stretching. The reaction between L-EtAc-liquid and pMDI resulted in Bio-PU resins with specific functional groups. The spectrum of Bio-PU resins obtained from LEtAc-liquid with pMDI showed $\mathrm{CH}_{3}$ and $\mathrm{CH}_{2}$ stretching that identified at $2985 \mathrm{~cm}^{-1}$. In addition, the absorption band of free $-\mathrm{N}=\mathrm{C}=\mathrm{O}$ groups was shifted to $2285 \mathrm{~cm}^{-1}$ from $2240 \mathrm{~cm}^{-1}$. The shifting of $-\mathrm{N}=\mathrm{C}=\mathrm{O}$ groups, due to the reaction with the $-\mathrm{OH}$ groups in L-EtAc-liquid, formed urethane groups $\left(\mathrm{R}-\mathrm{NH}-\mathrm{C}=\mathrm{O}-\mathrm{R}\right.$ ) at a weak absorption band at $1605 \mathrm{~cm}^{-1}$ (Lubis et al. 2019, 2020). However, the presence of free $-\mathrm{N}=\mathrm{C}=\mathrm{O}$ groups at $2285 \mathrm{~cm}^{-1}$ indicated that not all pMDI has reacted with L-EtAc-liquid fraction to form Bio-PU resins. The results were in agreement with published work that used technical grade of kraft lignin to prepare PU resins (Nacas et al. 2017).

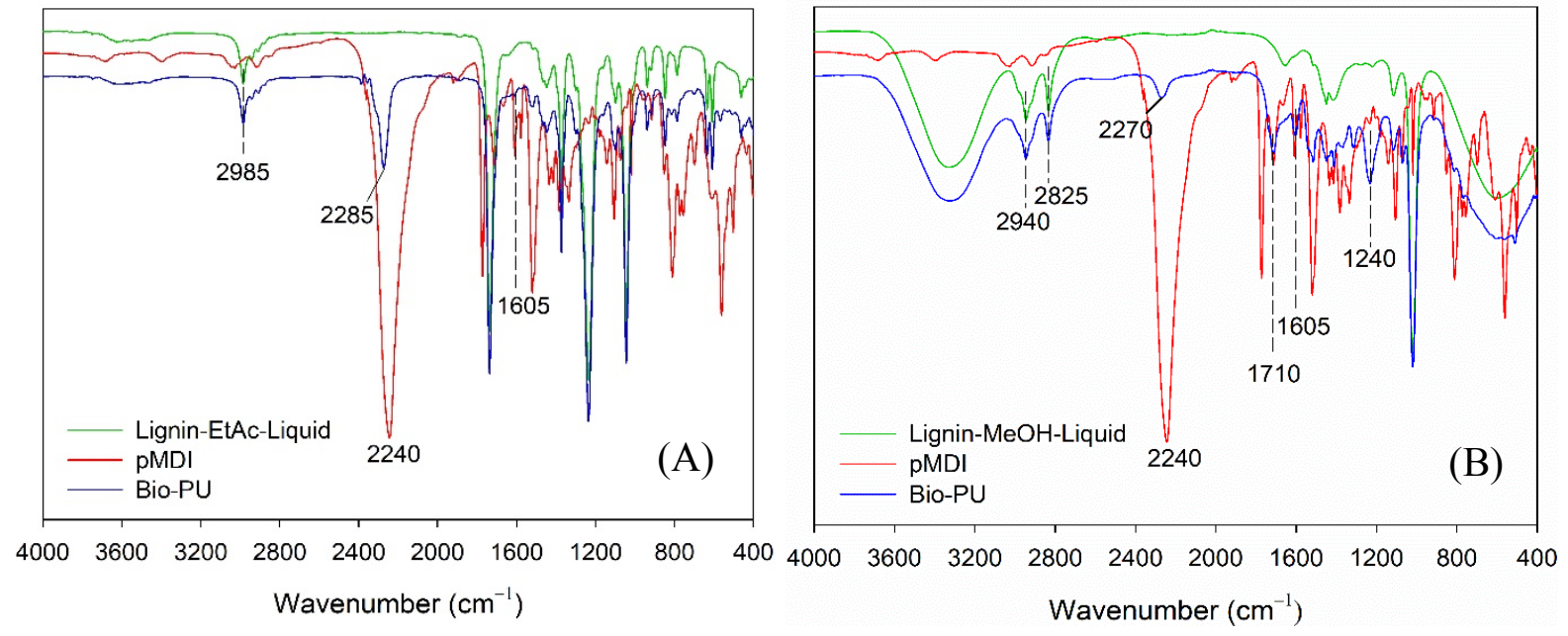

Fig. 7. FTIR spectra of liquid bio-polyurethane (Bio-PU) resins derived from fractionated lignin: (a) fractionated with ethyl acetate (EtAc), (b) fractionated with methanol $(\mathrm{MeOH})$

As depicted in Fig. 7b, Bio-PU resins have absorption bands at $2940 \mathrm{~cm}^{-1}$ and $2825 \mathrm{~cm}^{-1}$, corresponds to $\mathrm{C}-\mathrm{H}$ stretching $\left(\mathrm{CH}_{3}\right.$ and $\left.\mathrm{CH}_{2}\right)$. These absorption bands were also observed in L$\mathrm{MeOH}$-liquid. In addition, Bio-PU resins also had free $-\mathrm{N}=\mathrm{C}=\mathrm{O}$ groups at wavenumber of 2270 $\mathrm{cm}^{-1}$, shifting from $2240 \mathrm{~cm}^{-1}$. The peak of free $-\mathrm{N}=\mathrm{C}=\mathrm{O}$ groups in Bio-PU-L-MeOH was smaller than that in Bio-PU-L-EtAc. This indicates that pMDI has reacted more with $-\mathrm{OH}$ groups in L$\mathrm{MeOH}-$ liquid to form urethane groups $(\mathrm{R}-\mathrm{NH}-\mathrm{C}=\mathrm{O}-\mathrm{R})$ at $1605 \mathrm{~cm}^{-1}$ than that of L-EtAC-liquid. The band at $1710 \mathrm{~cm}^{-1}$ was assigned to $\mathrm{C}=\mathrm{O}$ of urethane in Bio-PU resins. The wavenumber of $1240 \mathrm{~cm}^{-1}$ was associated with $\mathrm{C}-\mathrm{N}$ stretching of urethane in Bio-PU resins. This result was in agreement with the published work (Nacas et al. 2017). Based on the result, the fractionation 
process was successfully used to prepare Bio-PU resins from fractionated lignin by reacting it with pMDI, where L-MeOH-liquid was more suitable as the Bio-PU pre-polymer.

Thermal properties of Bio-PU resins were monitored using DSC and TGA-DTG analysis. DSC thermograms of Bip-PU resins showed a $T_{g}$ at around $133^{\circ} \mathrm{C}$ and an endothermic peak at $T_{p}$ of $272^{\circ} \mathrm{C}$ for Bio-PU-L-EtAC, and a $T_{g}$ at $142^{\circ} \mathrm{C}$ and an endothermic peak at $T_{p}$ of $274^{\circ} \mathrm{C}$ for BioPU-L-MeOH (Fig. 8a). The $T_{g}$ of Bio-PU-L-EtAc was lower than that of Bio-PU-L-MeOH, indicating that the Bio-PU-L-MeOH had a more hard segment due to the urethane formation. Hard segment in PU resins is originated from urethane groups from the reaction of pMDI and polyol (Somdee et al. 2019). A similar trend was observed for the endothermic peak, which was attributed to the melting of Bio-PU resins. Bio-PU-L-EtAc had a lower $T_{p}$ of melting than that of Bio-PU-L$\mathrm{MeOH}$. This could be due to that Bio-PU-L-MeOH had more urethane groups and eventually produced more hard segments compared to Bio-PU-L-EtAc.
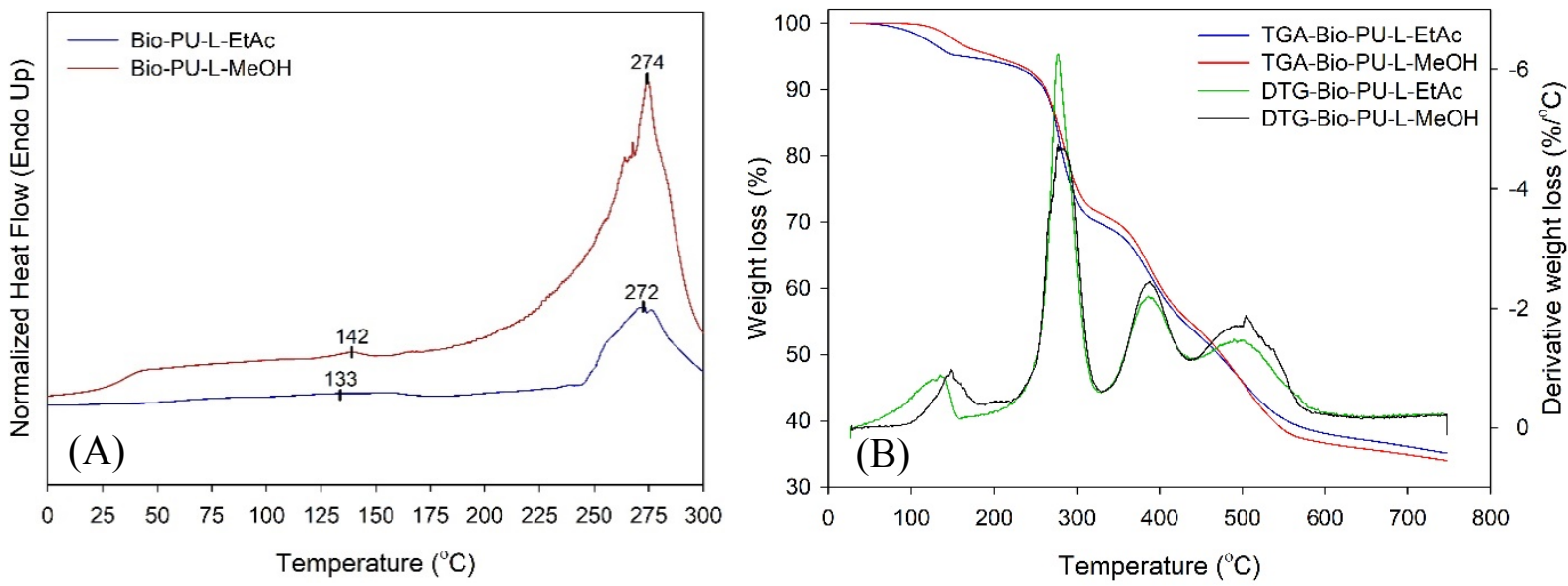

Fig. 8. Thermal properties of Bio-PU derived from lignin: (a) DSC, (b) TGA-DTG.

TGA-DTG analysis revealed that Bio-PU resins had four degradation peaks (Fig. 8b). The first degradation was detected at around $137^{\circ} \mathrm{C}$ for Bio-PU-L-EtAc and at $148^{\circ} \mathrm{C}$ for Bio-PU-L$\mathrm{MeOH}$, which could be due to the evaporation of residual water and solvent and glass transition of Bio-PU resins. This phenomenon was also detected by the results of DSC (Fig. 6a). At this step, the hard segment of Bio-PU resins changed its phase to a glassy state after the evaporation of residual water and solvent (Gama et al. 2019). The second degradation occurred at around $277^{\circ} \mathrm{C}$ for Bio-PU-L-EtAc and $282^{\circ} \mathrm{C}$ for Bio-PU-L-MeOH, which was due to the melting of Bio-PU resins. Further degradation was observed at a temperature around $390^{\circ} \mathrm{C}$ for both Bio-PU resins. This degradation belonged to the unreacted isocyanate in Bio-PU resins (Gama et al. 2019). The fourth degradation step was detected at around $500^{\circ} \mathrm{C}$, which was related to char formation from Bio-PU resins (Gama et al. 2019). The residual mass of Bio-PU resins was quite similar, with around 35\% for Bio-PU-L-EtAc and 34\% for Bio-PU-L-MeOH.

\subsection{Modification of Ramie Fibers}

Impregnation of ramie fibers was designed to improve the thermal stability and flame retardancy of ramie as a raw material for functional textiles. Fig. 9 displays the picture of ramie fibers before and after impregnation with Bio-PU resins. The original degummed ramie fibers were white, but the color changed to light brown after the impregnation with Bio-PU-L-EtAc and to dark brown with Bio-PU-L-MeOH. As can be seen in Fig. 1, the Bio-PU resins were brownish, 
therefore the color of impregnated ramie fibers changed to light brown and dark brown. The weight gain of ramie fibers after vacuum impregnation was quite similar for both Bio-PU resins at the same impregnation time (Table 1). Impregnation of ramie fibers with Bio-PU resins L-MeOH resulted in greater weight gain than those of Bio-PU L-EtAc, regardless of the impregnation time. This is probably due to the fact that more lignin was fractionated by $\mathrm{MeOH}$ for the preparation of Bio-PU resins than by EtAC. As can be seen in Fig. 7, less free -NCO groups were detected in Bio-PU-L-MeOH than those in Bio-PU-L-EtAc, meaning more Bio-PU resins were produced from $\mathrm{L}-\mathrm{MeOH}$. As expected, the weight gain of modified ramie fibers increased with longer impregnation time (Gindl et al. 2003).

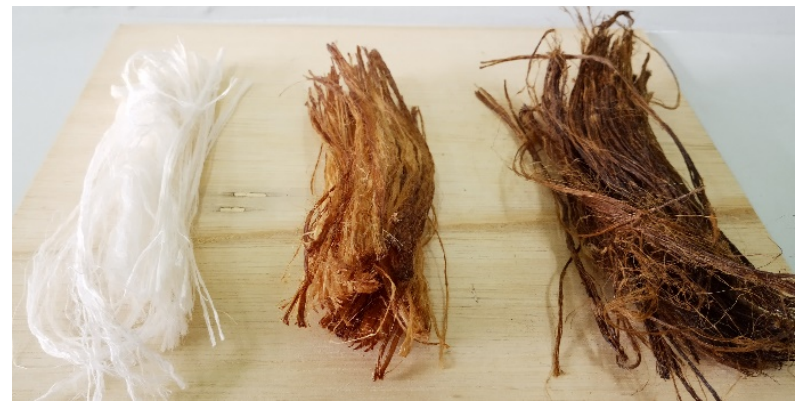

Fig. 9. Photograph of ramie fibers before impregnation (left), after impregnated with Bio-PUL-EtAc (center), and after impregnated with Bio-PU-L-MeOH (right).

Table 1. Weight gain (\%) of ramie fibers after impregnation with Bio-PU resins at different times Time (min)

Bio-PU resins

30

60

\begin{tabular}{lll}
\hline L-EtAc & $25.96 \pm 1.08$ & $29.68 \pm 0.42$ \\
L-MeOH & $29.08 \pm 0.83$ & $45.47 \pm 0.54$
\end{tabular}

As depicted in Fig. 10, ramie fibers before the impregnation process had six typical peaks at $3340 \mathrm{~cm}^{-1}, 2890 \mathrm{~cm}^{-1}, 1740 \mathrm{~cm}^{-1}, 1610 \mathrm{~cm}^{-1}, 1420 \mathrm{~cm}^{-1}$, and $1025 \mathrm{~cm}^{-1}$ that belonged to $\mathrm{O}-\mathrm{H}$ vibration, $\mathrm{C}-\mathrm{H}$ vibration carbohydrates, $\mathrm{C}=\mathrm{O}$ vibration of hemicellulose, $\mathrm{C}-\mathrm{H}$ bending of carbohydrates, $\mathrm{C}-\mathrm{O}$ of cellulose, respectively (Kandimalla et al. 2016). After impregnation with Bio-PU resins, the alteration of functional groups of ramie fibers was observed by FTIR. The peak of ramie fibers at $3340 \mathrm{~cm}^{-1}$ was shifted to $3330 \mathrm{~cm}^{-1}$ due to the reaction of $-\mathrm{OH}$ groups of ramie with -NCO groups of Bio-PU (Fig. 10a). Two new peaks at $2940 \mathrm{~cm}^{-1}$ and $2830 \mathrm{~cm}^{-1}$ that assigned to $\mathrm{N}-\mathrm{H}$ bending and $-\mathrm{CH}_{2}$ stretching of Bio-PU were observed in impregnated ramie fibers with Bio-PU resins. Moreover, peaks at $1740 \mathrm{~cm}^{-1}$ and $1610 \mathrm{~cm}^{-1}$ of ramie fibers were shifted down to $1710 \mathrm{~cm}^{-1}$ and $1600 \mathrm{~cm}^{-1}$, respectively, due to the formation of $\mathrm{C}=\mathrm{O}$ of urethane of Bio-PU resins (Fig. 10b). Therefore, several new peaks were formed in modified ramie fibers such as $1510 \mathrm{~cm}^{-1}$, $1310 \mathrm{~cm}^{-1}, 1220 \mathrm{~cm}^{-1}$, and $1055 \mathrm{~cm}^{-1}$. Those peaks were corresponding to $\mathrm{C}-\mathrm{N}$ stretching of primary and secondary amide, $\mathrm{C}=\mathrm{O}$ vibration from Bio-PU resins, $\mathrm{C}-\mathrm{O}-\mathrm{C}$ of ether linkages, respectively (Cateto et al. 2008). In addition, peaks at $820 \mathrm{~cm}^{-1}$ and $760 \mathrm{~cm}^{-1}$ were detected in ramie fibers after impregnation with Bio-PU resins, which originated from $-\mathrm{CH}_{2}$ rocking of isocyanate in Bio-PU resins. This result indicates that free $-\mathrm{NCO}$ groups (blue color) of Bio-PU resins reacted with the $-\mathrm{OH}$ groups (green color) on the surface of ramie fibers to form urethane linkages (red color), as displayed in Fig. 11. It is believed that some of Bio-PU resins were 
impregnated into ramie fibers after vacuum impregnation. However, microscopy investigation is needed to determine the depth of impregnation of Bio-PU resins into ramie fibers.
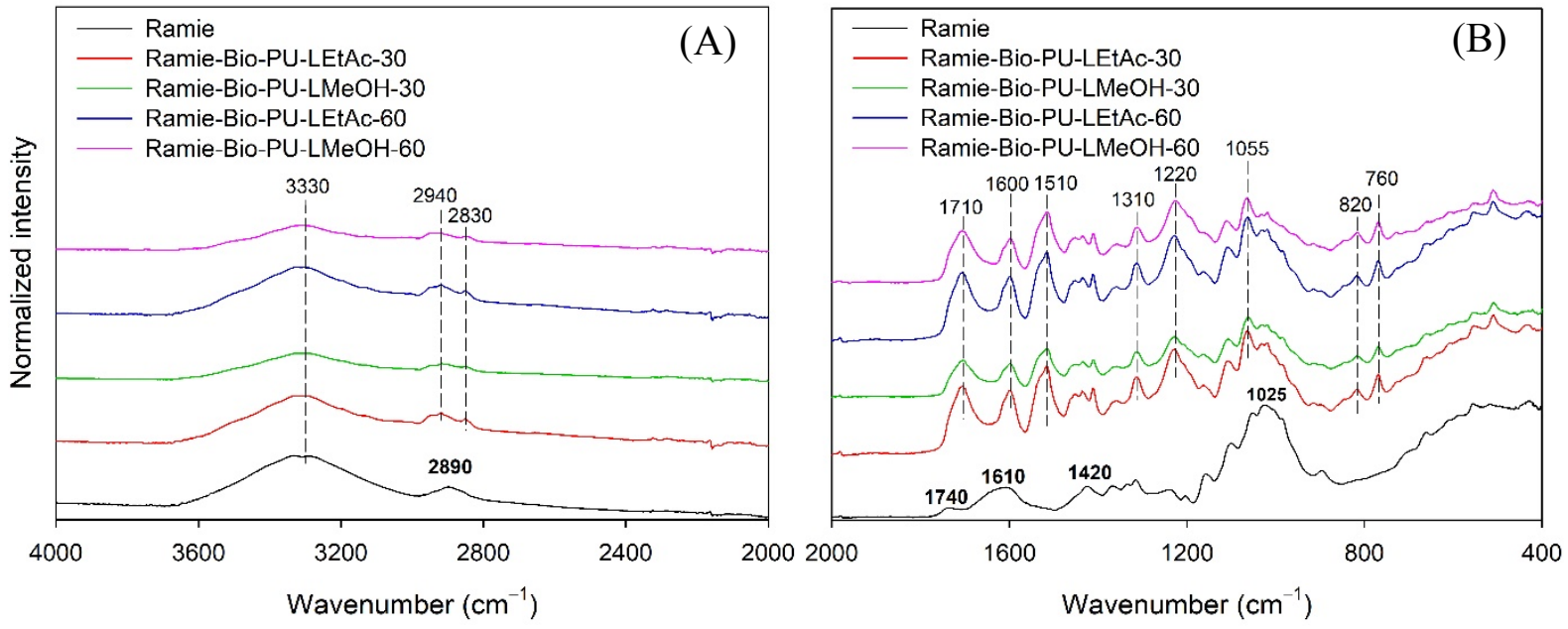

Fig. 10. Functional groups analysis of impregnated ramie fibers. (a) $4000-2000 \mathrm{~cm}^{-1}$, (b) 2000 $400 \mathrm{~cm}^{-1}$.
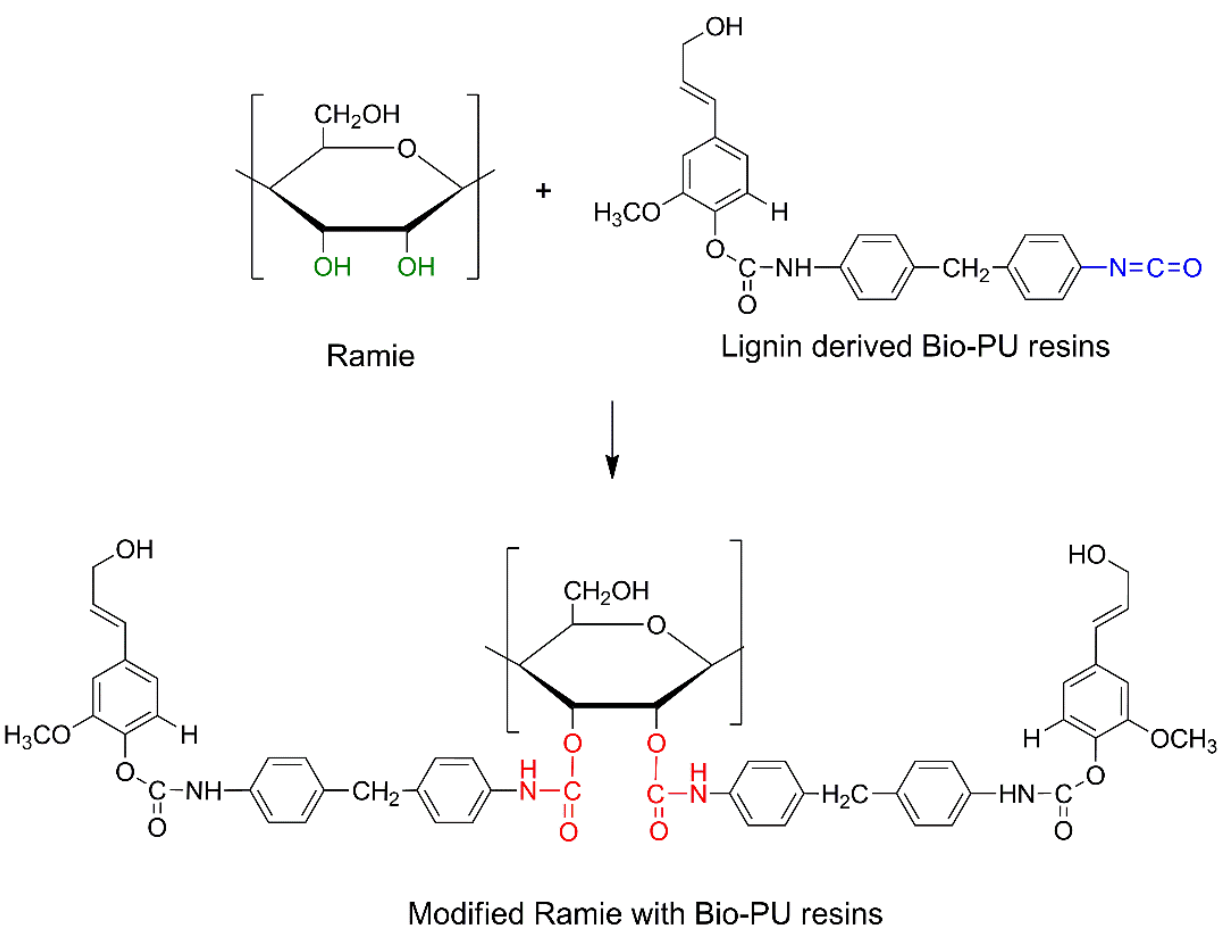

Fig. 11. Scheme reaction of ramie fibers impregnated with Bio-PU resins.

Thermal properties and stability of modified ramie fibers with Bio-PU resins were examined using DSC and TGA-DTG analysis. DSC analysis showed two reactions in ramie fibers, one endothermic reaction and an exothermic reaction (Fig. 12a). The endothermic reaction $\left(T_{p I}\right)$ occurred at around $46^{\circ} \mathrm{C}$ owing to moisture evaporation in ramie fibers (Poletto et al. 2015). Modification of ramie fibers with Bio-PU-L-MeOH resulted in similar $T_{p 1}$ at around $46-47^{\circ} \mathrm{C}$, while impregnation of Bio-PU-L-EtAc into ramie fibers increased the $T_{p 1}$ to around $59^{\circ} \mathrm{C}$ and $88^{\circ} \mathrm{C}$. It is known that EtAc has a higher boiling point than the $\mathrm{MeOH}$, around $77.1^{\circ} \mathrm{C}$ for EtAc and around $64.7^{\circ} \mathrm{C}$ for $\mathrm{MeOH}$. This could affect the $T_{p l}$ of modified ramie fibers. The exothermic peak $\left(T_{p 2}\right)$ of ramie fibers took place at around $330^{\circ} \mathrm{C}$ due to the formation of charring or solid 
residue (Shahinur et al. 2020). Impregnation of Bio-PU resins into ramie fibers increased the $T_{p 2}$ value to around $345^{\circ} \mathrm{C}$ until $360^{\circ} \mathrm{C}$, where Bio-PU-LEtAC gave higher $T_{p 2}$ than that of $\mathrm{MeOH}$.
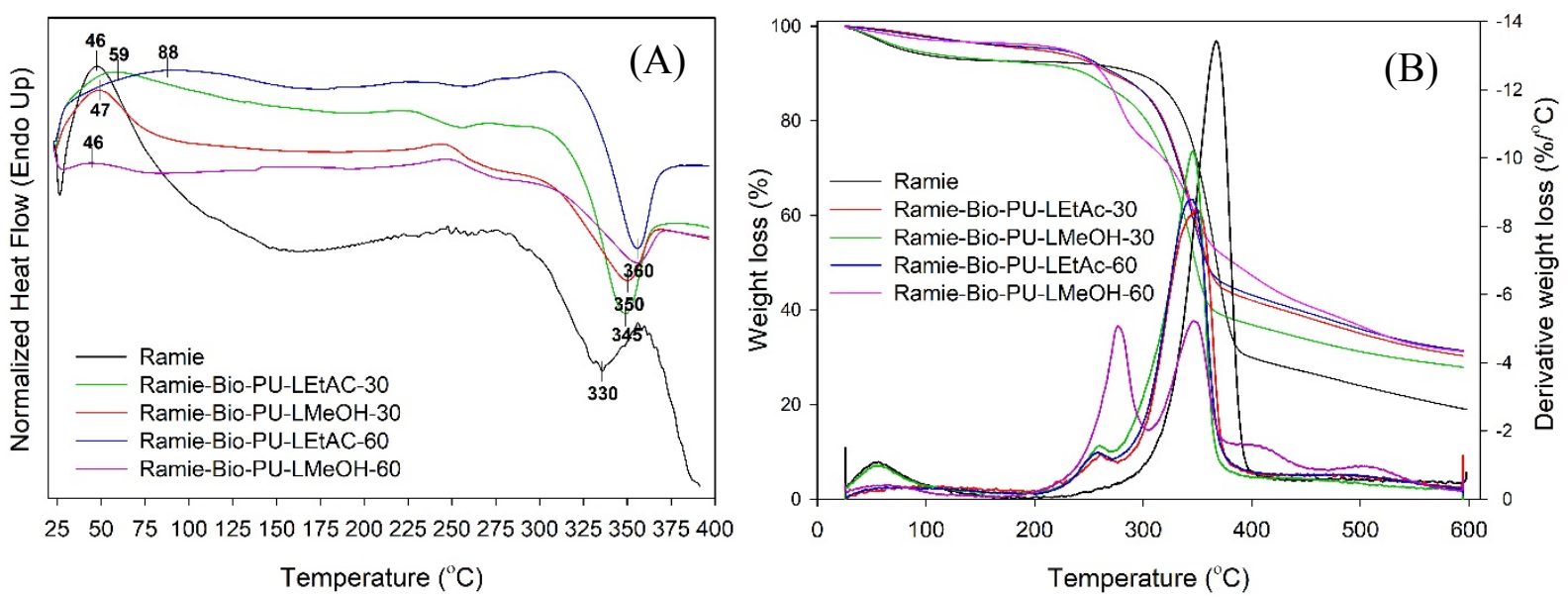

Fig. 12. Thermal properties of ramie fibers before and after impregnation. (a) DSC, (b) TGADTG.

TGA-DTG analysis revealed that modified ramie fibers with Bio-PU resins had greater thermal stability than that of original ramie fibers (Fig. 12b). The first degradation stage occurred due to water loss and low-molecular-weight components degradation, resulting in nearly $10 \%$ of weight loss. Impregnation remarkably increased the first degradation peak temperature from $50^{\circ} \mathrm{C}$ to around $100^{\circ} \mathrm{C}$, resulting in greater thermal stability as indicated by derivative weight loss of around $0.5 \% /{ }^{\circ} \mathrm{C}$. This stage was responsible for the thermal stability, therefore if the fiber is not sufficiently dried, the water contained in the sample can lead to a catastrophic failure when used as composite materials (Poletto et al. 2015). The second degradation stage was attributed to hemicellulose degradation that observed within a narrow range of temperature from $200^{\circ} \mathrm{C}$ to $300^{\circ} \mathrm{C}$, generating around $20-40 \%$ of weight loss. The derivative weight loss ranged from $2.0 \% /{ }^{\circ} \mathrm{C}$ to $4.5 \% /{ }^{\circ} \mathrm{C}$, where impregnation with Bio-PU-L-MeOH resulted in higher weight loss compared to Bio-PU-L-EtAC. The third stage was related to cellulose degradation at a higher temperature range between $320^{\circ} \mathrm{C}$ and $400^{\circ} \mathrm{C}$, producing around $50-80 \%$ of weight loss. The degradation is mainly due to the random cleavage of the glycosidic linkage of cellulose, in which the maximum weight loss generally occurs at $350^{\circ} \mathrm{C}$ (Poletto et al. 2015). Modification of ramie fibers with Bio$\mathrm{PU}$ resins generated derivative weight loss of around $5.0 \% /{ }^{\circ} \mathrm{C}$ to $10 \% /{ }^{\circ} \mathrm{C}$, while the original ramie fibers had around $14 \% /{ }^{\circ} \mathrm{C}$ of derivative weight loss. This indicated that the free $-\mathrm{NCO}$ groups BioPU resins have reacted with the $-\mathrm{OH}$ groups of ramie fibers as depicted in Fig. 11, thus resulted in greater thermal stability and lower weight loss. The weight residue of ramie fibers was around $18.5 \%$, while the modified ramie fibers had residue of around $28.1-32.5 \%$.

\section{Conclusions}

This study investigated the possibility of using lignin-derived bio-polyurethane (Bio-PU) resins to modify ramie fibers. Liquid fractions of lignin-ethyl acetate (L-EtAc) and ligninmethanol (L-MeOH) were used as pre-polymer of Bio-PU resins instead of conventional polyol. The Bio-PU resins were successfully prepared by mixing liquid fractions of lignin with $10 \%$ of pMDI as indicated by the formation of urethane $(\mathrm{R}-\mathrm{NH}-\mathrm{C}=\mathrm{O}-\mathrm{R})$ groups at $1605 \mathrm{~cm}^{-1}$ and the 
presence of free isocyanate (-NCO) groups at 2270-2280 $\mathrm{cm}^{-1}$. Modification of ramie fibers with Bio-PU resins using vacuum impregnation method was successfully performed. The formation of urethane $(\mathrm{R}-\mathrm{NH}-\mathrm{C}=\mathrm{O}-\mathrm{R})$ groups at $1600 \mathrm{~cm}^{-1}$ was detected in modified ramie fibers owing to the reaction between free $-\mathrm{NCO}$ groups of Bio-PU resins with $-\mathrm{OH}$ groups of ramie fibers. Impregnation of ramie fibers with Bio-PU resins remarkably improved the fibers' thermal stability by $10 \%$ to $15 \%$, depending on liquid fractions of lignin and the impregnation time. Combination of Bio-PU-L-EtAc and 60 min of impregnation time resulted in higher thermal retardancy ramie fibers compared to the original one. This study showed that lignin derived Bio-PU resins could be successfully used as a fire retardant to improve thermal stability and fire retardancy of ramie fibers.

\section{Acknowledgments}

This work was funded by the "Prioritas Riset Nasional (PRN)", Indonesian Ministry of Research and Technology (Ristek/BRIN), with a grant number of 172/E1/PRN/2020. Authors are also grateful for the facilities support from Integrated Laboratory of Bio-products (iLaB), Research Center for Biomaterials, Indonesian Institute of Sciences (LIPI).

\section{References}

Alinejad, M., Henry, C., Nikafshar, S., Gondaliya, A., Bagheri, S., Chen, N., Singh, S. K., Hodge, D. B., and Nejad, M. 2019. Lignin-Based Polyurethanes: Opportunities for Bio-Based Foams, Elastomers, Coatings and Adhesives. Polymers 11(7): 1202. DOI: 10.3390/polym11071202 Angelini, L. G., Lazzeri, A., Levita, G., Fontanelli, D., and Bozzi, C. 2000. Ramie (Boehmeria nivea (L.) Gaud.) and Spanish Broom (Spartium junceum L.) Fibres for Composite Materials: Agronomical Aspects, Morphology, and Mechanical Properties. Industrial Crops and Products 11(2-3): 145-161. DOI: 10.1016/S0926-6690(99)00059-X

Angelini, L. G., Scalabrelli, M., Tavarini, S., Cinelli, P., Anguillesi, I., and Lazzeri, A. 2015. Ramie Fibers in a Comparison Between Chemical and Microbiological Retting Proposed for Application in Biocomposites. Industrial Crops and Products 75: 178-184. DOI: 10.1016/j.indcrop.2015.05.004

Antov, P., Jivkov, V., Savov, V., Simeonova, R., and Yavorov, N. 2020a. Structural Application of Eco-Friendly Composites from Recycled Wood Fibres Bonded with Magnesium Lignosulfonate. Applied Sciences (Switzerland) 10(21): 1-12. DOI: 10.3390/app10217526

Antov, P., Krišst'ák, L., Réh, R., Savov, V., and Papadopoulos, A. N. 2021. Eco-Friendly Fiberboard Panels from Recycled Fibers Bonded with Calcium Lignosulfonate. Polymers 13(4): 639. DOI: 10.3390/polym13040639

Antov, P., Savov, V., and Neykov, N. 2020b. Sustainable Bio-Based Adhesives for Eco-Friendly Wood Composites: A Review. Wood Research 65(1): 51-62. DOI: 10.37763/wr.13364561/65.1.051062

Boerjan, W., Ralph, J., and Baucher, M. 2003. Lignin biosynthesis. Annual Review of Plant Biology 54(1): 519-546. DOI: 10.1146/annurev.arplant.54.031902.134938

Buranov, A. U., Ross, K. A., and Mazza, G. 2010. Isolation and Characterization of Lignins Extracted from Flax Shives using Pressurized Aqueous Ethanol. Bioresource Technology 101(19): 7446-7455. DOI: 10.1016/j.biortech.2010.04.086

Cateto, C. A., Barreiro, M. F., and Rodrigues, A. E. 2008. Monitoring of Lignin-Based Polyurethane Synthesis by FTIR-ATR. Industrial Crops and Products 27(2): 168-174. DOI: 10.1016/j.indcrop.2007.07.018

Chauhan, M., Gupta, M., Singh, B., Singh, A. K., and Gupta, V. K. 2014. Effect of Functionalized Lignin on the Properties of Lignin-Isocyanate Prepolymer Blends and Composites. European 
Polymer Journal 52: 32-43. DOI: 10.1016/j.eurpolymj.2013.12.016

Cui, C., Sadeghifar, H., Sen, S., and Argyropoulos, D. S. 2013. Toward Thermoplastic Lignin Polymers; Part II: Thermal \& Polymer Characteristics of Kraft Lignin \& Derivatives. BioResources 8(1): 864-886. DOI: 10.15376/biores.8.1.864-886

Djafar, Z., Renreng, I., and Jannah, M. 2020. Tensile and Bending Strength Analysis of Ramie Fiber and Woven Ramie Reinforced Epoxy Composite. Journal of Natural Fibers 0478. DOI: 10.1080/15440478.2020.1726242

Dorez, G., Taguet, A., Ferry, L., and Lopez-Cuesta, J. M. 2013. Thermal and Fire Behavior of Natural Fibers/PBS Biocomposites. Polymer Degradation and Stability 98(1): 87-95. DOI: 10.1016/j.polymdegradstab.2012.10.026

Du, S. L., Lin, X. B., Jian, R. K., Deng, C., and Wang, Y. Z. 2015. Flame-Retardant Wrapped Ramie Fibers towards Suppressing "Candlewick Effect" of Polypropylene/Ramie Fiber Composites. Chinese Journal of Polymer Science 33(1): 84-94. DOI: 10.1007/s10118-0151560-z

El Mansouri, N. E., and Salvadó, J. 2007. Analytical Methods for Determining Functional Groups in Various Technical Lignins. Industrial Crops and Products 26(2): 116-124. DOI: 10.1016/j.indcrop.2007.02.006

Falah, F., Lubis, M. A. R., Triastuti, T., Fatriasari, W., and Sari, F. P. 2020. Utilization of Lignin from the Waste of Bioethanol Production as a Mortar Additive. Jurnal Sylva Lestari 8(3): 326. DOI: $10.23960 /$ js138326-339

FAO. 2019. Forest Products 2019. Rome.

Gama, N., Ferreira, A., and Barros-Timmons, A. 2019. Cure and Performance of Castor Oil Polyurethane Adhesive. International Journal of Adhesion and Adhesives 95: 102413. DOI: 10.1016/j.ijadhadh.2019.102413

García, A., Toledano, A., Serrano, L., Egüés, I., González, M., Marín, F., and Labidi, J. 2009. Characterization of Lignins Obtained by Selective Precipitation. Separation and Purification Technology 68: 193-198. DOI: 10.1016/j.seppur.2009.05.001

Gindl, W., Zargar-Yaghubi, F., and Wimmer, R. 2003. Impregnation of Softwood Cell Walls with Melamine-Formaldehyde Resin. Bioresource Technology 87: 325-330. DOI: 10.1016/S0960-8524(02)00233-X

Griffini, G., Passoni, V., Suriano, R., Levi, M., and Turri, S. 2015. Polyurethane Coatings based on Chemically Unmodified Fractionated Lignin. ACS Sustainable Chemistry and Engineering 3(6): 1145-1154. DOI: 10.1021/acssuschemeng.5b00073

Hermiati, E., Risanto, L., Lubis, M. A. R., Laksana, R. P. B., and Dewi, A. R. 2017. Chemical Characterization of Lignin from Kraft Pulping Black Liquor of Acacia mangium. in: AIP Conference Proceedings. DOI: 10.1063/1.4973132

Jönsson, A. S., Nordin, A. K., and Wallberg, O. 2008. Concentration and Purification of Lignin in Hardwood Kraft Pulping Liquor by Ultrafiltration and Nanofiltration. Chemical Engineering Research and Design 86(11): 1271-1280. DOI: 10.1016/j.cherd.2008.06.003

Jung, S., Joo, H., Jin, E., Song, Y., and Bae, H. 2015. Isolation and Characterization of Lignin from the Oak Wood Bioethanol Production Residue for Adhesives. International Journal of Biological Macromolecules 72: 1056-1062. DOI: 10.1016/j.ijbiomac.2014.10.020

Kandimalla, R., Kalita, S., Choudhury, B., Devi, D., Kalita, D., Kalita, K., Dash, S., and Kotoky, J. 2016. Fiber from Ramie Plant (Boehmeria nivea): A Novel Suture Biomaterial. Materials Science and Engineering C 62: 816-822. DOI: 10.1016/j.msec.2016.02.040

Krutov, S. M., Voznyakovskii, A. P., Gribkov, I. V., and Shugalei, I. V. 2014. Lignin Wastes: Past, Present, and Future. Russian Journal of General Chemistry 84(13): 2632-2642. DOI: 10.1134/S1070363214130222

Li, N., Yan, H., Xia, L., Mao, L., Fang, Z., Song, Y., and Wang, H. 2015. Flame Retarding and Reinforcing Modification of Ramie/Polybenzoxazine Composites by Surface Treatment of Ramie Fabric. Composites Science and Technology 121: 82-88. DOI: 
10.1016/j.compscitech.2015.07.013

Lubis, M. A. R., Park, B. D., and Lee, S. M. 2019. Performance of Hybrid Adhesives of BlockedpMDI/Melamine-Urea-Formaldehyde Resins for the Surface Lamination on Plywood. Journal of the Korean Wood Science and Technology 47(2): 200-209. DOI: 10.5658/WOOD.2019.47.2.200

Lubis, M. A. R., Park, B. D., and Lee, S. M. 2020. Microencapsulation of Polymeric Isocyanate for the Modification of Urea-Formaldehyde Resins. International Journal of Adhesion and Adhesives 100: 102599. DOI: 10.1016/j.jjadhadh.2020.102599

Mimini, V., Sykacek, E., Hashim, S. N. A., Holzweber, J., Hettegger, H., Fackler, K., Potthast, A., Mundigler, N., and Rosenau, T. 2019. Compatibility of Kraft Lignin, Organosolv Lignin and Lignosulfonate With PLA in 3D Printing. Journal of Wood Chemistry and Technology 39(1): 14-30. DOI: 10.1080/02773813.2018.1488875

Nacas, A. M., Ito, N. M., Sousa, R. R. De, Spinacé, M. A., and Dos Santos, D. J. 2017. Effects of NCO:OH Ratio on the Mechanical Properties and Chemical Structure of Kraft Lignin-Based Polyurethane Adhesive. The Journal of Adhesion 93(1-2): 18-29. DOI: 10.1080/00218464.2016.1177793

Poletto, M., Ornaghi Junior, H. L., and Zattera, A. J. 2015. Thermal Decomposition of Natural Fibers: Kinetics and Degradation Mechanisms. in Reactions and Mechanisms in Thermal Analysis of Advanced Materials (eds A. Tiwari and B. Raj). DOI: 10.1002/9781119117711.ch21

Shahinur, S., Hasan, M., Ahsan, Q., and Haider, J. 2020. Effect of Chemical Treatment on Thermal Properties of Jute Fiber Used in Polymer Composites. Journal of Composites Science 4(3): 132. DOI: $10.3390 /$ jcs4030132

Solihat, N. N., Sari, F. P., Falah, F., Ismayati, M., Lubis, M. A. R., Fatriasari, W., Santoso, E. B., and Syafii, W. 2021. Lignin as an Active Biomaterial: A Review. Jurnal Sylva Lestari 9(1): 1-22. DOI: $10.23960 /$ js1191-22

Somdee, P., Lassú-Kuknyó, T., Kónya, C., Szabó, T., and Marossy, K. 2019. Thermal Analysis of Polyurethane Elastomers Matrix with Different Chain Extender Contents for Thermal Conductive Application. Journal of Thermal Analysis and Calorimetry 138(2): 1003-1010. DOI: 10.1007/s10973-019-08183-y

Tejado, A., Peña, C., Labidi, J., Echeverria, J. M., and Mondragon, I. 2007. Physico-Chemical Characterization of Lignins from Different Sources for Use in Phenol-Formaldehyde Resin Synthesis. Bioresource Technology 98: 1655-1663. DOI: 10.1016/j.biortech.2006.05.042

Toledano, A., García, A., Mondragon, I., and Labidi, J. 2010. Lignin Separation and Fractionation by Ultrafiltration. Separation and Purification Technology 71: 38-43. DOI: 10.1016/j.seppur.2009.10.024

Velez, J., and Thies, M. C. 2013. Solvated Liquid-Lignin Fractions from a Kraft Black Liquor. Bioresource Technology 148: 586-590. DOI: 10.1016/j.biortech.2013.08.097

Wang, Y.-Y., Wyman, C. E., Cai, C. M., and Ragauskas, A. J. 2019. Lignin-Based Polyurethanes from Unmodified Kraft Lignin Fractionated by Sequential Precipitation. ACS Applied Polymer Materials 1(7): 1672-1679. DOI: 10.1021/acsapm.9b00228

Wenger, J., Haas, V., and Stern, T. 2020. Why Can We Make Anything from Lignin Except Money? Towards a Broader Economic Perspective in Lignin Research. Current Forestry Reports Current Forestry Reports 6(4): 294-308. DOI: 10.1007/s40725-020-00126-3

Yuan, J. M., Feng, Y. R., and He, L. P. 2016. Effect of Thermal Treatment on Properties of Ramie Fibers. Polymer Degradation and Stability 133: 303-311. DOI: 10.1016/j.polymdegradstab.2016.09.012 